\title{
Evaluating the 2013 Euro CAC Experiment
}

\author{
Elena Carletti \\ Paolo Colla \\ Mitu Gulati*
}

\section{$\underline{\text { I. Introduction }}$}

The subject of this volume is "The New Financial Architecture in the Eurozone". As one might expect, since this is about the "new architecture", most of the essays in this volume are forward looking in terms of talking about pieces of the architecture yet to be put in place. Our essay is instead backward looking. It looks at one of the pieces of this architecture that was put in place two years ago, in January 2013; the Euro CAC. There may be lessons to be learned from this Euro CAC experiment in terms of what to do (or not to do) going forward.

On January 1, 2013, it became mandatory that every new sovereign bond issued by a member of the European Monetary Union include a new contract clause called a Collective Action Clause or CAC. ${ }^{1}$ This, we believe, constituted the biggest one-time change to the terms of sovereign debt contracts in history, impacting a market of many trillions of euros. And it was not just that the change was big in terms of the size of the market it impacted; it was big in terms of its impact on the documentation of each individual Euro area sovereign bond contract. To illustrate, prior to January 1, 2013, all of the terms of a local-law Irish sovereign bond fitted on about a page and a half; the full document was about three pages long. After January 1,2013 , the document was twenty pages long; almost all of that space taken by the new CAC term. It was a big change. But did it do anything? And, more importantly, did it do what it was intended to do?

The Euro CAC initiative was put in place in the wake of the sovereign debt crisis that hit the Euro area in late 2009. The goal, as announced by the Euro area finance ministers on November 28, 2010, was to "safeguard financial stability". ${ }^{2}$ The task of designing this Euro CAC and implementing the initiative was delegated to what is called the "Bonds and Bills Committee", a committee comprised of the debt managers of all the EU area countries that meets regularly in Brussels to discuss matters of common concern. Under the leadership of the head of the French Treasury, and with an eminent US law firm advising it, this committee took

\footnotetext{
* Carletti and Colla are faculty at Bocconi University (Finance) and Gulati is at Duke University (Law). For comments, thanks to organizers, Franklin Allen and Joanna Gray, and to the participants at the EUI conference on "New Financial Architecture", held in April 2015.

1 There was an exception for bonds of maturities under a year and bonds being tapped from bond issuance programs already in place. The latter exception, however, could only be used to a limited extent and had to be gradually phased out.

2 See http://europa.eu/efc/sub_committee/cac/cac_2012/final_-_cac_public_report.pdf
} 
somewhere between a year and two years of regular meetings (once a month in Brussels, typically) to design their clauses (Gelpern \& Gulati 2013). It is hard to estimate exactly how much time and effort went into the production of these new Euro CACs, but with at least eighteen countries at the negotiating table on a monthly basis, each of which would have probably had multiple bureaucrats and lawyers working on preparing for the meetings and then attending, it must have been thousands of man hours that went into this project. Roughly two years after the initiative was put into place, we can begin evaluating its impact. Did the initiative achieve what it was aimed at?

That then raises the question of what the initiative was aimed at achieving. The announcement of the Euro area finance ministers in November 2010, said that the initiative was meant to "safeguard financial stability". But that is too vague to evaluate. If we dig deeper into what policy makers seem to have intended at the time though, it seems clear that their original intent was to send a message to the markets that there would be "PSI" or "private sector involvement" in restructurings in the future. That is, that in the future all of the burdens of a sovereign debt failure in the Euro area would not be put on the taxpayers via bailouts; instead taxpayers private investors would have to take a hit if the countries they invested in got into serious debt problems. Putting in provisions into the bonds that detailed precisely how these future restructurings would take place was a clear way of sending such a message. For example, an Irish investors holding an twenty-page post-2013 Irish bond that had more than a dozen pages detailing how a restructuring of his bonds would take place would surely notice the difference between that and the threepage pre-2013 Irish bond that said nothing about a restructuring. In the latter, he would be hard pressed to claim that he had not had notice that a restructuring of his debt was a possibility.

The question to ask then is: Did the markets get the message that was intended? Did they see these post 2013 bonds, with their new CAC terms, are more likely to be restructured than their pre 2013 non-CAC compatriots.

The case we make in this essay is that, at least based on preliminary indications, there is reason to be concerned that the policy goals of the Euro CAC project (regardless of whether they were laudable ones) were not achieved. If so, then the question that should be asked by policy makers is why not? Or, put differently, what should have been done differently?

\section{CACs: Some Background}

Collective Action Clauses or CACs are easily the most studied contract provisions in sovereign bonds; they may well be the most studied contract provision in any setting whatsoever. The reason they have garnered so much attention is that on multiple occasions over the past few decades, they have been seen as providing a solution to global financial crises that hit the sovereign debt markets. The standard in sovereign bonds for much of the past century was that if a debtor wanted to get a 
reduction in its obligations, that reduction had to be individually approved by each bondholder. In practical terms, a large scale restructuring of a bond with many thousands of dispersed holders was near impossible. The end result then, for a sovereign in default, would be either that the Official Sector, fearing the contagion that might occur from a protracted default, would provide a bailout (e.g., Mexico in 1995) or the sovereign would be mired in years of litigation (e.g., Argentina over the past decade). Neither outcome was viewed as good.

CACs are provisions that make it easier for a sovereign debtor to do a debt workout, by allowing a supermajority of creditors to accept a deal for the entire creditor group (a contractual cram down of dissenting creditors) (Portes 2004). At least three times over the past century, policy makers ranging from expert committees of the League of Nations in the 1920s, to the authors of the Rey Report in 1995 all the way to Angela Merkel and Nicholas Sarkozy taking a beach walk in Deauville in October 2010, have proposed the introduction of CACs as a way to fix problems with the sovereign debt market (Weidemaier \& Gulati 2013). In every instance, an immediate response to the policy proposal from market actors has been the query: "But won't the introduction of these new terms raise the cost of capital?"

The first initiative, that of the League of Nations in the 1920s, did not come to fruition, with the CAC proposal not even making it to the final report of the League Committee in charge of proposing changes. The second CAC initiative, that began roughly in 1995, was aimed at foreign-law emerging market sovereign bonds issued primarily in New York. This initiative, starting in 2003, was an enormous success in terms of the rate of voluntary adoption of the CACs proposed by a G10 committee of experts (almost 100\%). And dozens of academic papers were written, both before and after the 2003 initiative, analyzing the question of whether the new terms would (or have) increased or reduced the cost of capital.

We will not get into the details of the prior academic work, both for reasons of space and because the Euro CAC experiment turned out to be quite different than the one undertaken a decade prior in the New York market for emerging markets sovereign issuers. The focus of the prior studies was foreign-law governed bonds whose terms typically already required a high vote for them to be altered (typically, unanimous approval). The CACs that were being put in place in these foreign-law emerging market bonds were going to make restructurings easier in moving from a high vote requirement (usually, unanimity) to a lower one (usually 75\%). The Euro CAC initiative was different in that it was taking local-law governed bonds that had no CACs and putting in CACs (with a vote between $66.67 \%$ and $75 \%$ ). As we will explain in more detail below, using the context of the Greek restructuring of 2012, it is not at all clear from the outset that inserting a CAC into a local-law bond will make restructuring easier. The reason being that "local law" bonds can arguably altered at whim by the local government. In such a context, why would one expect a CAC to have any effect at all?

\section{The Euro CACs}


The sovereign debt crisis that hit the Euro area nations in 2010-2013 went through a number of stages. Initially, there were big bailouts with transfers of funds from the richer nations to the poorer ones. And later, there was a brutal restructuring in one country, Greece. To say that there was political and economic fallout from the crisis and the missteps that were taken in trying to fix it is to put it mildly. As a result, the Euro area policy makers put in place a number of policy measures aimed at ensuring that the resolution of future sovereign debt crises would not be quite so costly to the Eurosystem. The initiative that most directly impacted the sovereign debt market was the imposition of an identical debt restructuring mechanism, via contract, in all Euro area sovereign bonds that were issued after January 1, 2013.

In constructing the Euro CAC initiative, Euro area policy makers had borrowed from a US Treasury Department initiative from roughly a decade prior, in 2002-03. That initiative, constructed in the wake of the sovereign bailouts of the mid 1990s and the default of Argentina in 2001, was focused on emerging market issuers (mostly Latin American) who were issuing sovereign bonds to mostly foreign investors under New York law. The Euro area version of the initiative, however, was significantly more ambitious than the emerging market version in three ways. The size was larger (it applied to a multi trillion dollar market as compared to one that was a in the tens of billion), the scope was wider (applied via the local laws of eighteen different Euro member nations as opposed to one foreign law (New York)), and the CAC provisions in question were more powerful (applying in an aggregated fashion across a full set of a nation's bonds, as opposed to on a bond by bond basis). As noted at the outset, the Euro CAC initiative of 2013 engineered, at one blow, the single biggest change to sovereign bond contract terms ever - and this is a market that has been around for at least five centuries, if not more.

CACs, as noted, are contract provisions that allow for a majority of creditors in a single bond, or sometimes even across an issuer's full series bonds, bonds, to vote to modify the payment obligations to the debtor (with the permission of the debtor). Put simply, they are a mechanism that allows for the debtor in crisis and a majority of creditors (usually a supermajority, between $66.67 \%$ and $75 \%$ ) to agree to a restructuring of obligations that the debtor owes in a fashion that forces the deal on a minority of dissenting creditors (holdouts). Prior to January 2013, the overwhelming majority of bonds of Euro area countries (over $95 \%$ of a market of upwards of $\$ 10$ trillion in outstanding bonds) contained no such contract provisions. If these had been foreign-law governed bonds, a Euro area sovereign wanting to restructure them would have had to go to each individual bondholder and ask her to voluntarily take a haircut; an impossible task. But these were locallaw governed bonds; meaning that the local legislature could write new terms into them. As a result, Greece, prior to its March 2012 restructuring, was able to legislatively impose a specially designed set of CACs on its local-law bonds and then conduct its restructuring.

\section{The Euro CACs: Predictions}


What was the predicted impact of the Euro CAC policy move? Looking back through the policy briefs, press reports and academic articles written at the time tells us that there was variation in terms of what policy makers expected from the Euro CAC initiative.

Initially, and before the Greek restructuring of 2012, there were those (perhaps the majority) who saw the Euro CAC move as profoundly anti-creditor; and particularly so vis-à-vis the holders of bonds of the weaker Euro area nations. Certainly, this was the intended message of the Franco-German announcement on October 18, 2010 (made after the infamous Deauville beach walk). Private creditors were now forewarned that they could be restructured (Gelpern \& Gulati 2013). If there was a sovereign crisis in the future, private creditors could no longer expect to be bailed out (in Greece, at least for the first few years of the crisis, the private creditors were bailed out in full). Under this view, one might predict that the CAC bonds would be perceived as riskier than the non-CAC ones; after all, the CAC ones were the ones where bondholders were told explicitly that a restructuring was possible in the future.

The Euro CAC initiative, as some policy makers have explained to us, initially had a dual purpose. The hope was to both produce the effect of assuring current bondholders (in non-CAC local-law bonds) that they were safe (because CACs would only be put in place after Jan 1,2013 ) and also to assuage the concerns of taxpayers (who were worried, in late 2010, that they would be repeatedly on the hook for providing repeated bailouts to the weakest nations of the Euro area). As it turned out though, bondholders did not believe the message. The announcement of the CAC initiative in late $2010 \mathrm{did}$ not calm the markets; if anything, investors may have taken the announcement as a sign that restructurings were coming, and soon (Gelpern \& Gulati 2013). Within a year, the markets were proved right in that it was announced that Greece would be pursuing a restructuring of its bonds. In March 2012 , that announcement was implemented in brutal fashion via a retroactive legislative imposition of a special set of CACs on all Greek local-law bonds (Zettelmeyer, Trebesch \& Gulati 2014). ${ }^{3}$

One might ask at this stage, after the Greek restructuring in 2012, whether there was any more need for the Euro CAC initiative. After all, the fact that the message that non-CAC local law bonds were safer than CAC bonds could no longer be sent (the March 2012 restructuring by Greece arguably put an end to that). But the Euro CAC initiative did not get abandoned. Perhaps policy makers thought that the markets would believe their repeated assertions that Greece restructuring was "unique and exceptional".

3 There was an exception made for a subset of bonds held by Euro area official sector institutions such as the European Central Bank. 
Some of the policy makers who were interviewed about the foregoing put forward a more nuanced explanation for why the Euro CAC initiative went forward. The new story justifying the Euro CAC initiative, these policy makers asserted, was that the initiative would send a pro-creditor message. Instead of telling creditors that restructurings would be more likely in the future, the new story was that CACs were a commitment not to do a Greek retroactive change in the law in the future. The Greek restructuring was, to reiterate, was "unique and exceptional." Unlike with Greece, where the sovereign had retroactively imposed a vote requirement on its bonds after it had figured out how many votes it had (or so we suspect), thereby making it near impossible for bondholders to hold out against deals they thought were unsatisfactory, the vote requirements would now be clear and uniform for everyone from the start. The prediction, under this pro creditor story then is the opposite of that under the first story: the local-law bonds with CACs here should have lower yields than their non-CAC counterparts because the CAC bonds, in the case of a restructuring, would be assured an orderly restructuring process where the rules of the game would be known in advance (unlike with Greece and unlike with the non-CAC local law bonds).

The question in evaluating the CAC initiative then is whether it resulted in assuring the markets that CAC bonds would fare better (or worse) in future restructurings than the non-CAC ones. Prior to implementation, policy makers seem to have made predictions going both ways.

\section{Some Preliminary Insights}

The dataset we utilize is drawn from a variety of sources (Bloomberg, Dealogic, and Thomson One Banker). It is made up of 85 CAC bonds for 13 Eurozone sovereigns issued between January 1, 2013 and June 31,2014 with maturity larger than one year (Austria, Belgium, Finland, France, Germany, Ireland, Italy, Luxemburg, the Netherlands, Portugal, Slovakia, Slovenia, Spain). All bonds are either zero coupon or have a fixed coupon. Figure 1 displays the issuance activity of CAC bonds in our sample, over time. By the end of the first quarter of 2013 all countries had issued at least one bond with a CAC. Figure 2 plots the time-series of the amount outstanding (the sum of original issues and further tap issues ${ }^{4}$ ) of CAC bonds in Eurozone countries, both in absolute terms and relative to the overall amount of long-term government debt. ${ }^{5}$ Figure 2 shows that at the end of June 2014 about $13 \%$ of longterm bonds included the new Euro CAC provision.

\footnotetext{
4 After issuing a new bond, governments can raise additional debt by reopening already existing securities (socalled tap issues).

${ }^{5}$ Data for long-term government debt outstanding are sourced from the ECB Statistical Data Warehouse. For each country, we consider long-term government debt as the sum of long-term residual maturities (over 1 year) and short-term residual maturities (up to 1 year), in all currencies.
} 


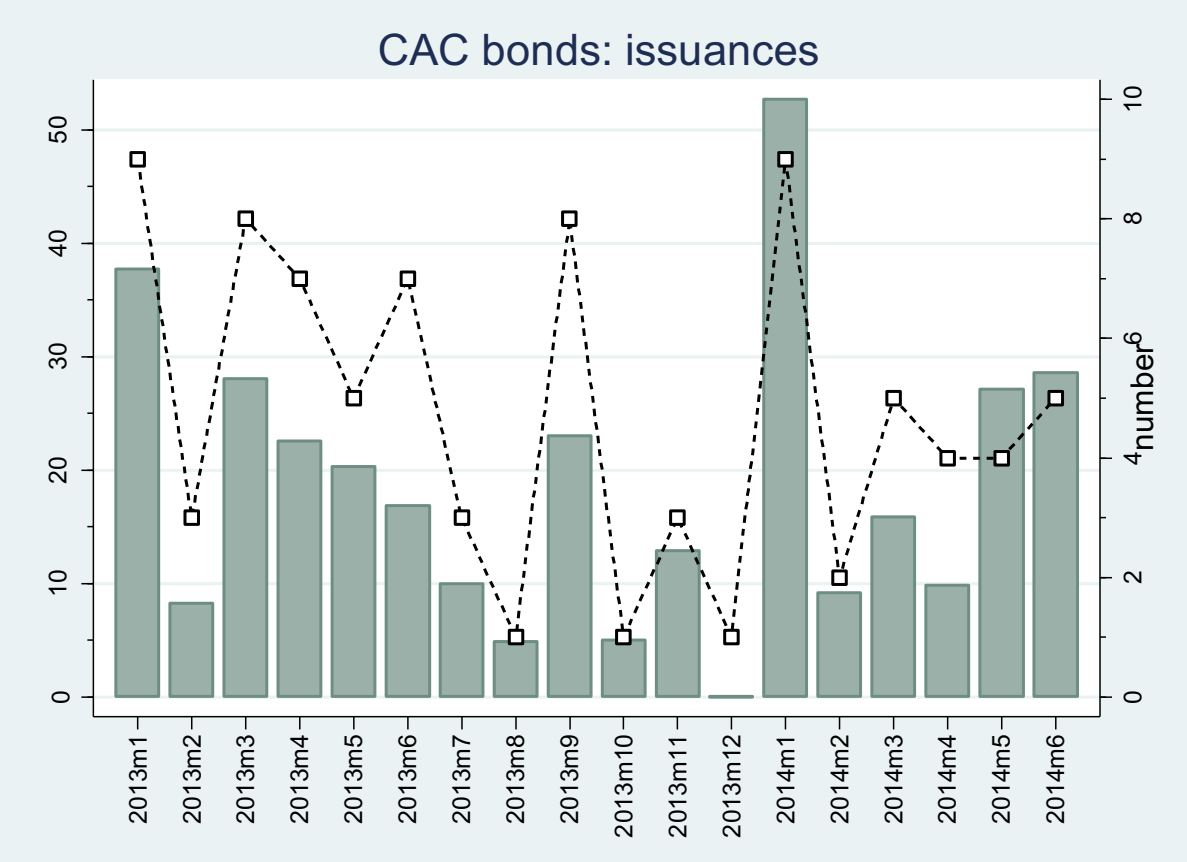

Fig. 1. CAC bonds issuances. Monthly time series of CAC bonds issuances by aggregate amount (grey bars, left vertical axis) and by number of issuances (squares, right vertical axis).

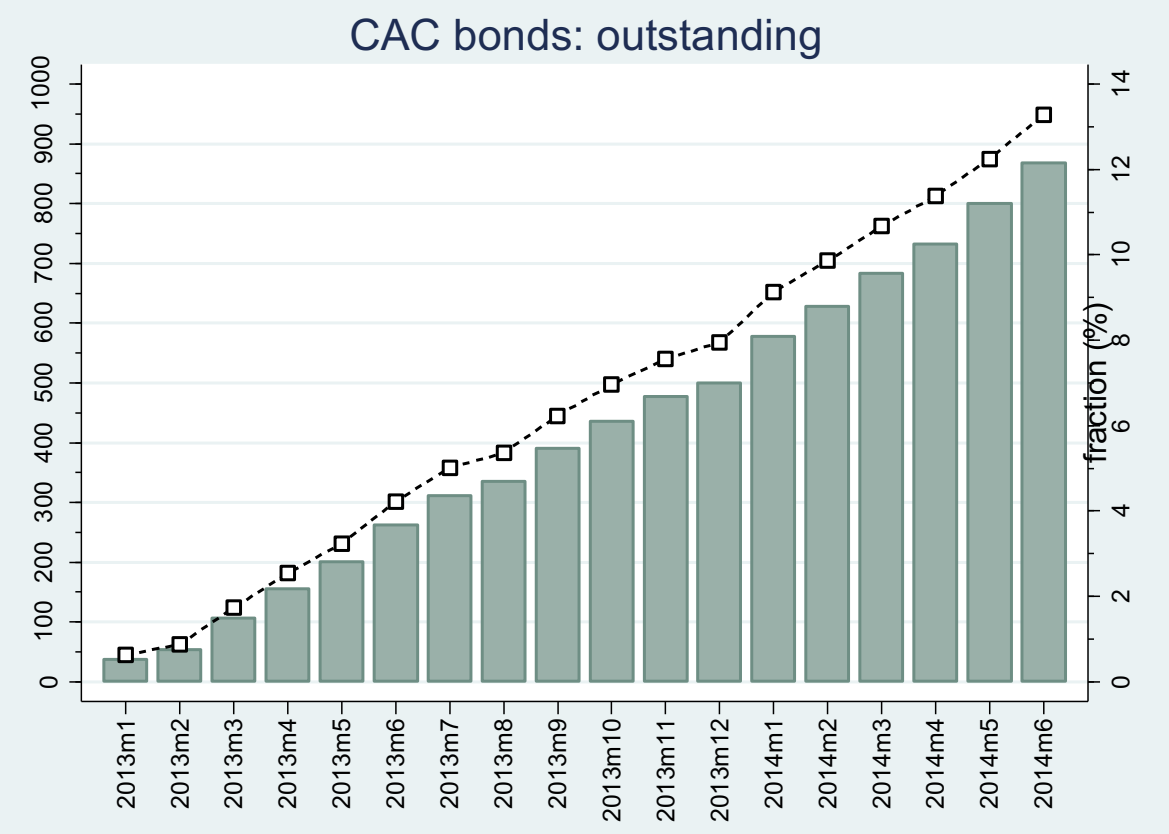

Fig. 2. CAC bonds outstanding. Monthly time series of CAC bonds outstanding by aggregate amount (grey bars, left vertical axis) and by fraction of total long-term government outstanding (squares, right vertical axis).

The joint message of Figures 1 and 2 is that CAC bonds are becoming more and more important in the context of Eurozone sovereign debt markets. We now turn to the 
question at the heart of the inquiry: Do markets see the bonds with CACs as being different from those without them in terms of the risk of being restructured?

To gather preliminary evidence on this matter, we select four CAC bonds with five years maturity issued by different countries (Austria, Finland, France, and Spain). We pair each of these bonds with a non-CAC bond issued before January 1, 2013 by the same issuer, with the same currency and roughly the same residual maturity, and then compare the daily yields of CAC and non-CAC bonds.

In Figure 3 we plot the yields of our bonds. We do not find that our CAC bonds consistently have higher yields than their non-CAC counterparts for the four countries under consideration. ${ }^{6}$ Nor, for that matter, do we find the converse. For instance, the 5 year bonds issued by Austria and Finland enjoy, on average, yields lower by, respectively, 7.5bps and $15.8 \mathrm{bps}$ than non-CAC bonds with similar maturity. On the other hand, for France and Spain we observe larger yields of CAC versus non-CAC bonds. Although in economic terms these yield differentials may seem small, they are all statistically significant. At first cut then, the evidence suggests that CACs did not have their intended effects. Indeed, the effects seem to sometimes go in one direction and at other times in the opposite direction. Further, they seem to have had some explicitly unintended effects. The reason we say that is that the CAC initiative was explicitly intended - as per the directives of the treaty -- to operate in the same fashion across all the Euro area countries. ${ }^{7}$ Put differently, while the individual effects in particular countries might have been expected to be different (with stronger effects in the weaker countries than in the stronger ones), the effects were all supposed to go in the same direction. But that is not what we see. The question is why.

\footnotetext{
${ }^{6}$ A recent DIW Economic Bulletin report also looks at the relative yields for Euro area CAC and non CAC bonds, observes the differences to be quite minimal, and asks the question of why this reform (particularly in the local law bond context) was embarked on in the first place (Steffen \& Schumacher 2014).

${ }^{7}$ Article 12(3) of the ESM Treaty stated:

Collective Action Clauses shall be included, as of January 1, 2013, in all new euro area government securities with maturity above one year, in a way that ensures that their legal impact is identical.
} 


\section{References}

Gelpern, Anna, Gulati, Mitu, 2007. Public symbol in private contract: a case study. Washington University Law Quarterly 84, 1627-1715.

Gelpern, Anna \& Mitu Gulati. 2013. The Wonder-Clause. Journal of Comparative Economics. 41(2): 367-385.

Portes, Richard. 2004. Resolution of Sovereign Debt Crises: The New Old Framework. CEPR Discussion Paper 4717.

Steffen, Christoph \& Julian Schumacher. 2014. Debt Restructuring in the Euro Area: How Can Sovereign Debt be Restructured More Effectively? DIW Wochenbericht Economic Bulletin 10.2014.

Weidemaier, Mark C. \& Mitu Gulati. 2013. A People's History of Collective Action Clauses. Virginia Journal of International Law. 54(1): 52-86.

Zettelmeyer, Jeromin, Christoph Trebesch \& Mitu Gulati. 2014. The Greek Debt Restructuring: An Autopsy. Economic Policy. 28: 513-563. 


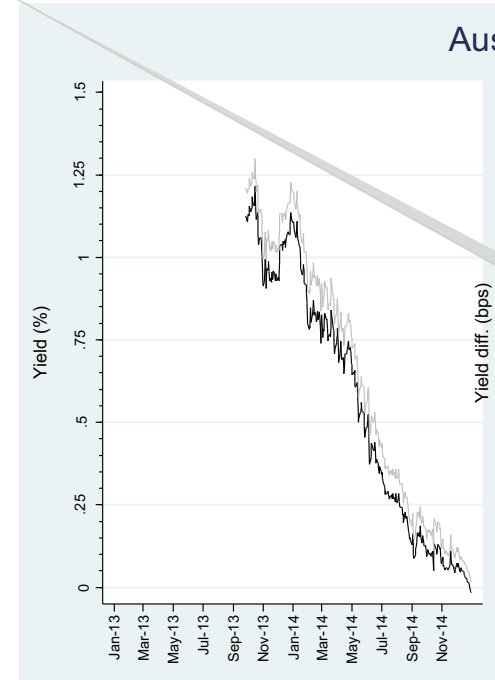

\section{Austria}
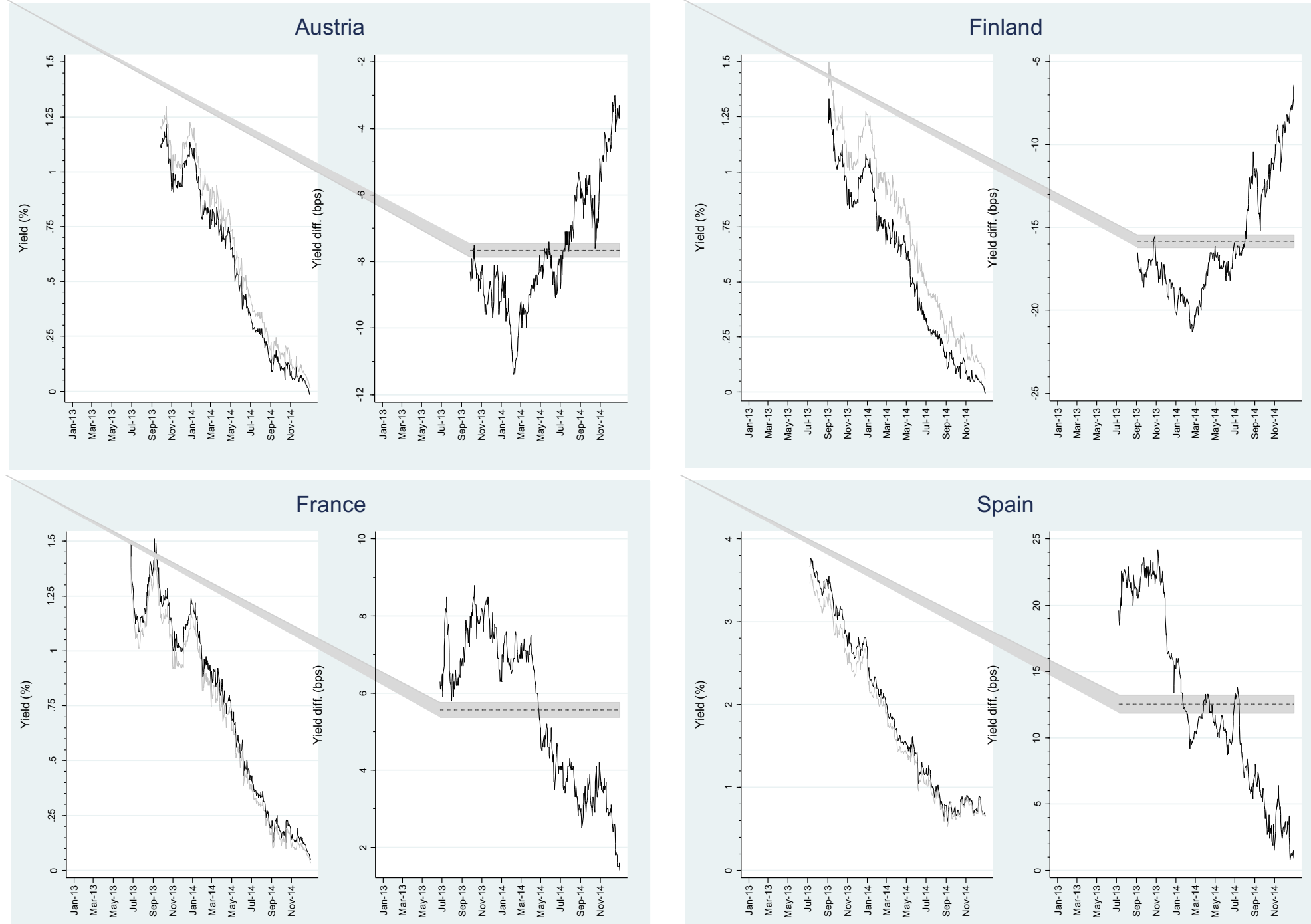

France
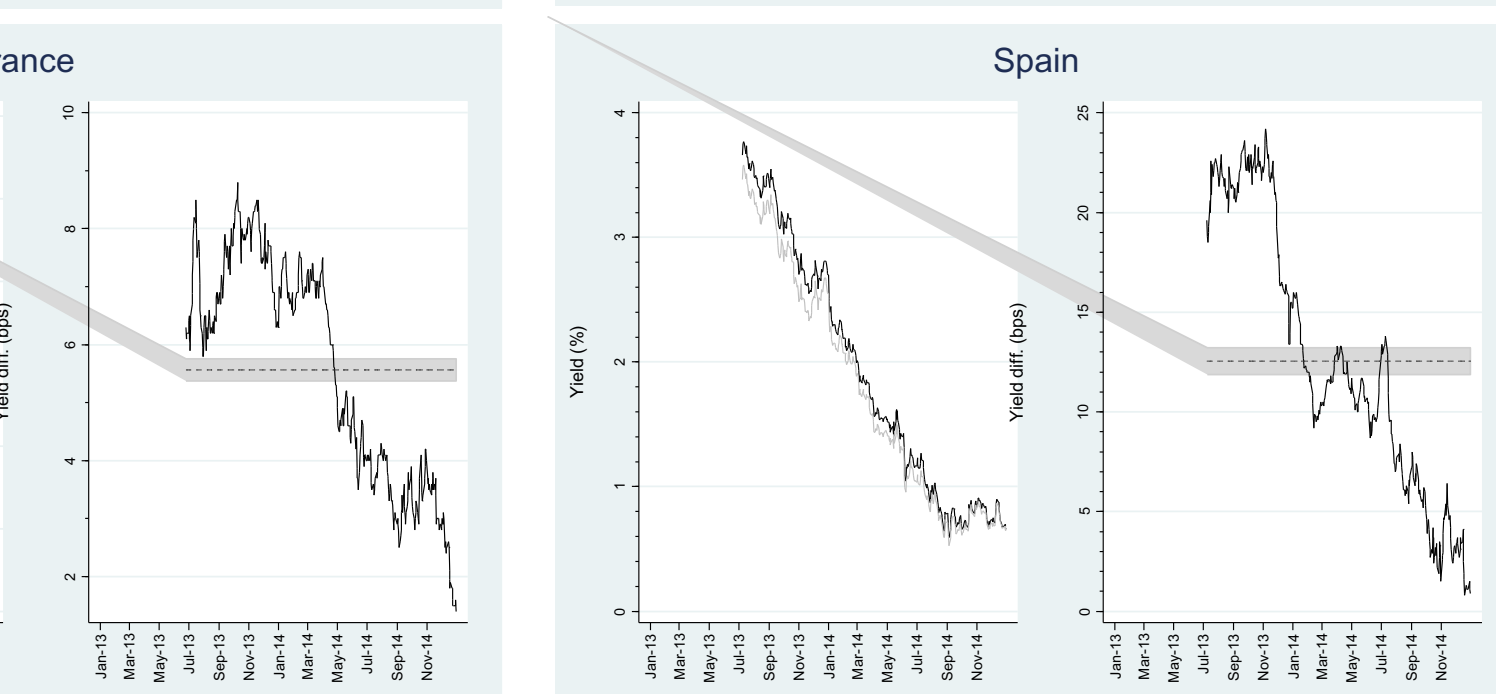

Fig. 3. Yield and yield differential between CAC and non-CAC bonds. For each country, the left panel plots yields (in percentage) on CAC bonds (black line) issued with 5 yrs maturity and those of matched non-CAC bonds (grey line). The right panel plots the yield differential (CAC minus non-CAC bond, in bps) for each bond pair, together with the average yield differential (dashed black line) and its $95 \%$ confidence interval. For Austria we consider the $1.15 \%$ bond with maturity Oct 2018 (ISIN: AT0000A12B06) and the 4.35\% bond with maturity Mar 2019 (AT0000A08968); for Finland we consider the 1.125\% bond with maturity Sep 2018 (FI4000068663) and the $4.375 \%$ bond with maturity Jul 2019 (FI0001006306); for France we consider the 1\% bond with maturity Nov 2018 (FR0011523257) and the 4.25\% bond with maturity Oct 2018 (FR0010670737); for Spain we consider the 3.75\% bond with maturity Oct 2018 (ES00000124B7) and the 4.1\% bond with maturity Jul 2019 (ES00000121A5). 